\title{
PERSEPSI DOSEN TERHADAP PENERAPAN PRINSIP- PRINSIP DEMOKRASI DALAM PEMILIHAN KETUA DAN SEKRETARIS PRODI PADA FAKULTAS IPPS IKIP PGRI PONTIANAK
}

\author{
Muhammad Anwar Rube'i ${ }^{1}$, Rohani ${ }^{2}$ \\ ${ }^{1,2}$ Program Studi Pendidikan Pancasila dan Kewarganegaraan \\ Fakultas Ilmu Pendidikan dan Pengetahuan Sosial IKIP PGRI Pontianak \\ Jalan Ampera Nomor 88 Pontianak - 78116, Telepon (0561) 748219 Fax. (0561) 589855 \\ ${ }^{1}$ Alamat e-mail: anwarptk87@ gmail.com
}

\begin{abstract}
Abstrak
Penelitian ini bertujuan memperoleh informasi tentang persepsi dosen terhadap penerapan prinsip-prinsip demokrasi dalam pemilihan Ketua dan Sekretaris Prodi pada Fakultas IPPS IKIP PGRI Pontianak. Penelitian ini menggunakan metode kualitatif dengan bentuk penelitian deskriptif analitis. Subyek dalam penelitian ini yaitu dekan dan dosen Fakultas IPPS.Teknik pengumpulan data dan informasi dilakukan melalui teknik observasi, wawancara, studi literatur, dan studi dokumentasi. Analisis data menggunakan teknik analisis data kualitatif. Hasil temuan dalam penelitian ini menunjukkan bahwa persepsi dosen terhadap penerapan prinsip-prinsip demokrasi dalam pemilihan ketua dan sekretaris Program Studi pada Fakultas Ilmu Pendidikan dan Pengetahuan Sosial sudah berjalan dengan baik dan harus tetap dijaga, dipertahankan serta membudayakan prinsip-prinsip demokrasi pada setiap sistem pelaksanaan demokrasi pada IKIP PGRI Pontianak. Pelaksanaan prinsip-prinsip demokrasi yang dilaksanakan yaitu, (1) prinsip demokratis, (2) prinsip kebebasan, (3) prinsip partisipasi, (4) prinsip kesetaraan, (5) prinsip kejujuran, (6) prinsip saling menghargai dan menghormati.
\end{abstract}

Kata Kunci: Persepsi, prinsip-prinsip demokrasi, pemilihan ketua dan sekretaris Prodi

\begin{abstract}
This study aims to obtain information about lecturers' perceptions of applying the principles of democracy in the election of Chairman and Secretary of Departmen at the Faculty of IPPS IKIP PGRI Pontianak. This research uses qualitative method with analytical descriptive research form. The subjects in this research are deans and lecturers of Faculty of IPPS. Data and information gathering technique is done through observation technique, interview, literature study, and documentation study. Data analysis using qualitative data analysis techniques. The findings of this study indicate that the lecturer's perception of the application of democratic principles in the election of the chairman and secretary of the Study Program at the Faculty of Education and Social Sciences is well underway and must be maintained, defended and civilized the principles of democracy in every system of democratic implementation at IKIP PGRI Pontianak. Implementation of democratic principles implemented are (1) democratic principles, (2) principles of freedom, (3) principles of participation, (4) principles of equality, (5) principles of honesty, (6) principles of mutual respect and respect.
\end{abstract}

Keywords: Perception, democratic principles, election of Departmen chairman and secretary

\section{PENDAHULUAN}


Pada hakekatnya perkembangan demokrasi di Indonesia sudah banyak mengalami perubahan, terutama setelah lahirnya reformasi yang menuntut adanya perbaikan sendi-sendi kehidupan baik dalam segi ideologi, ekonomi, politik, social, budaya maupun pertahanan dan keamanan. Kehidupan masyarakat pada era globalisasi sekarang ini perlu disikapi dengan baik oleh pemerintah bahwa setiap sendi kehidupan memerlukan koridor yang mampu menaungi masalah kenegaraan terutama yang erat kaitannya dengan kehidupan demokrasi. Oleh sebab itu maka semua bentuk penyimpangan dalam hal kehidupan demokrasi perlu diselesaikan agar tidak merusak tatanan sendi kehidupan yang lain, yang nantinya dapat merusak semangat demokrasi itu sendiri. Kenyataan ini, menurut Sumantri (1998:4) disebut "undemocratic democracy," yakni suatu tatanan kehidupan berbangsa dan bernegara yang struktur (institusi) demokrasinya sudah ada, tetapi semangat dan perwujudannya masih jauh dari cita-cita demokrasi.

Dengan memperhatikan fenomena kehidupan demokrasi dalam suasana "undemocratic-inconstitusional" di masyarakat maupun dilingkungan pendidikan seperti sekolah dan perguruan tinggi, maka perlu kiranya segera membangun "democratic culture" yang kuat serta ditopang oleh penanaman nilai-nilai,prinsip dan kaidah demokrasi dalam kehidupan berbangsa dan bernegara. Sejalan dengan hal tersebut Tilaar (1999:145-146) menyatakan bahwa “...ada dua kekuatan utama yang mengubah dunia yaitu proses demokratisasi serta kemajuan teknologi komunikasi dan dunia yang terbuka"

Untuk dapat mengajarkan kehidupan berdemokrasi, perlu memahami prinsip demokrasi dan menciptakan budaya demokrasi yang membutuhkan proses pembelajaran dan pengamalan. Kita perlu mengetahui bahwa budaya demokrasi tidak dapat dilakukan secara instant. Hal ini dinyatakan oleh Gandal and Finn (1992:2) bahwa "Democracy does not teach itself. If the strengths, benefits, and responsibilities of democracy are not made clear to citizens, they will be ill-equipped to defend it".hal ini berarti dapat dimaknai, bahwa demokrasi tidak bisa mengajarkannya sendiri. Jika kekuatan, kemanfaatan, dan tanggung jawab demokrasi tidak dipahami dan dihayati dengan baik oleh warga negara, sukar diharapkan mereka mau berjuang untuk mempertahankannya. Selain itu, 
menurut Alexis de Toqueville (Branson, 1998:2) mengemukakan "democracy is not a machine that would go on itself, but must be consciously reproduced, one generation after another", hal ini dapat dipahami bahwa demokrasi bukan seperti mesin yang akan berfungsi dengan sendirinya, tetapi harus secara sadar direproduksi dari satu generasi ke generasi berikutnya. Untuk itu, secara substantif dalam dimensi jangka panjang, yakni untuk mambangun karakter bangsa yang demokratis, pendidikan demokrasi mutlak diperlukan. Jika tidak dilaksanakan secara "trial and error" atau "taken for granted", tetapi didesain secara sistemik dan sistematis untuk membina dan mengembangkan prinsip-prinsip, nilai dan budaya warga negara demokratis, partisipatif dan berkeadaban dalam kehidupan bermasyarakat, berbangsa dan bernegara.

Menurut Winataputra (2008:9) berpendapat bahwa pendidikan kewarganegaraan di persekolahan (school civics) memiliki peranan strategis dalam mewujudkan pengembangan budaya kewarganegaraan demokratis, karena pendidikan kewarganegaraan merupakan salah satu modal dasar dalam mewujudkan kehidupan bermasyarakat yang berbudaya dan beradab. Untuk tujuan itu, maka kurikulum dan proses pembelajaran perlu diupayakan agar lebih mengarah pada tujuan pembangunan karakter bangsa yang diwujudkan dalam bentuk transformasi pengetahuan kewarganegaraan (civic knowledge), perilaku kewarganegaraan (civic disposition), dan kemampuan kewarganegaraan (civic skills) yang dapat mendukung berkembangnya budaya kewarganegaraan (civic culture).

Dalam konteks di atas, maka pendidikan kewarganegaraan berperan sebagai wahana sistemik pendidikan demokrasi (Winataputra, 2001), yang secara praksis-kurikuler semestinya tidak hanya dalam kerangka "learning to know" (belajar memahami konsep, prinsip, dan nilai-nilai demokrasi), tetapi harus merupakan proses berperilaku demokratis (learning to do), serta sebagai proses hidup dan berkehidupan demokratis dalam masyarakat majemuk di Indonesia (learning to be and learning to live together), hari ini dan mendatang. Oleh karena itu, menurut Gandal dan Finn (1992:4), pendidikan kewarganegaraan juga tidak dilihat sebagai "isolated subject" (pelajaran yang 
terisolasi), yang diajarkan hanya dalam waktu terjadwal saja, tetapi harus dikaitkan dengan banyak hal yang dipelajari siswa, termasuk banyak hal yang terjadi di luar sekolah.

Langkah utama dalam membangun budaya demokrasi di perguruan tinggi adalah menjadikan kampus menjadi media inseminasi dan pemekaran nilai-nilai demokrasi bagi kehidupan individu dan peran publiknya. Untuk itu, maka secara teoretis dan praktis, ada tiga hal yang harus diwujudkan, yaitu pertama, proses pembelajaran, kepemimpinan dan sistem manajemen di perguruan tinggi, dan budaya perkuliahan yang demokratis.

Berkaitan dengan membangun budaya demokrasi di kampus maka sikap mental dan perilaku individu harus mencerminkan konsep wawasan, nilai, norma dan prinsip demokrasi dalam diri individu warga kampus itu sendiri. menurut Winataputra dan Tim CCE (2007:11-13), budaya kewarganegaraan demokratis sebagai berikut :

1. Pro bono publico yaitu sikap mengutamakan kepentingan publik diatas kepentingan pribadi atau golongan.

2. Pro patricia primes patrialis yaitu sikap mengutamakan kepentingan negara.

3. Toleran atau menghargai dan menghormati pendapat orang lain yang berbeda.

4. Terbuka menerima pendapat orang lain.

5. Tanggap dan berani mengemukakan pendapat dengan baik dan benar.

6. Bersikap kritis terhadap informasi atau pandangan sehingga tidak mudah menerima dan menolak pandangan orang lain.

7. Cerdas dan penuh pertimbangan dalam mengambil keputusan.

8. Menghormati hak orang lain; Menghormati kekiiasaan yang sah.

9. Bersikap adil dan tidak diskriminatif.

10. Menjaga dan melaksanakan amanah dengan penuh tanggung jawab.

Dalam rangka mengoptimalkan perilaku budaya demokrasi maka sebagai generasi penerus yang akan mempertahankan negara demokrasi, perlu mendemonstrasikan bagaimana peran serta kita dalam pelaksanaan pesta 
demokrasi. Selain itu, menurut Sanusi (2006:193-205) ada sepuluh (The Ten Pillars of Indonesian Constitutional Democracy), diantaranya, demokrasi yang ber-ketuhanan yang maha esa, demokrasi dengan kecerdasan, demokrasi yang berkedaulatan rakyat, demokrasi dengan "rule of law", demokrasi dengan pembagian kekuasaan negara, demokrasi dengan hak azasi manusia, demokrasi dengan pengadilan yang merdeka, demokrasi dengan otonomi daerah, demokrasi dengan kemakmuran, dan demokrasi yang berkeadilan sosial.

Dengan memahami urgensi budaya demokrasi dan pilar-pilar demokrasi di atas, maka diharapkan mampu menterjemahkannya dalam bentuk wujud sikap dan perilaku yang demokratis pula, baik dalam kehidupan di masyarakat maupun dalam kultur kampus. dalam lingkungan kampus, sikap demokratis biasanya diwujudkan dalam proses belajar dalam perkuliahan. Selain itu, sikap demokratis bisa diwujudkan oleh civitas akademik kampus dalam pemilihan rektor, dekan dan wakil dekan, ketua program studi dan sekretaris program studi.

Namun, dalam praktik pelaksanaan nilai dan prinsip demokrasi di kampus IKIP-PGRI Pontianak masih terdapat distorsi pemahaman terkait nilai-nilai dan prinsip demokrasi yang baik dan benar dalam praktik tatanan kehidupan. Pemahaman dan persepsi yang masih parsial terhadap nilai dan prinsip demokrasi mengakibatkan kecenderungan seseorang untuk bersikap apatis, acuh tak acuh dan bahkan tidak perduli terhadap praktik-praktik demokrasi. Seharusnya, kita harus memahami dengan baik dan benar terhadap nilai dan prinsip demokrasi, terutama dalam praktik demokrasi di sebuah lembaga pendidikan seperti di perguruan tinggi. Dalam praktiknya, perguruan tinggi sudah pasti memiliki sistem organisasi dalam melaksanakan peranannya sebagai lembaga pendidikan yang memiliki visi, misi, tujuan serta program kerja yang diputuskan bersama oleh stackholder. Kebijakan dan keputusan yang dibuat oleh perguruan tinggi dalam merumuskan visi, misi, tujuan serta program kerja haruslah berdasarkan nilai dan prinsip demokrasi yang baik dan benar agar semua civitas akademika perguruan tinggi secara bersama-sama melaksanakan kebijakan tersebut dengan penuh rasa tanggungjawab. 
Berdasarkan uraian di atas, maka peneliti bermaksud untuk melakukan penelitian lebih mendalam mengenai "Persepsi Dosen Terhadap Penerapan Prinsip-Prinsip Demokrasi Dalam Pemilihan Ketua dan Sekretaris Prodi Pada Fakultas Ilmu Pendidikan Dan Pengetahuan Sosial IKIP PGRI Pontianak”.

\section{METODE PENELITIAN}

Dalam penelitian ini menggunakan pendekatan kualitatif. Menurut Moleong (2003:3), bahwa : “ penelitian kualitatif merupakan proedur penelitian yang menghasilkan data kualitatif berupa kata-kata tertulis maupun lisan dari orang perilaku yang diamati”. Penelitian kualitatif berakar pada latar belakang alami sebagai keutuhan, mengandalkan analisis secara induktif, mengarahkan sasaran penelitiannya pada usaha untuk menemukan teori dasar, bersifat deskriptif, lebih mementingkan proses dari pada hasil, membatasi studi dengan focus ,memiliki seperangkat criteria untuk memeriksa keabsahan data, rancangan penelitian bersifat sementara, dan hasil penelitiannya disepakati kedua belah pihak yaitu penelitian dan subjek penelitian. Metode yang digunakan dalam penelitian ini adalah deskriptif analitik.

Lokasi penelitian ini adalah kampus IKIP PGRI Pontianak khusnya Fakultas Ilmu Pendidikan dan Pengetahuan Sosial yang beralamat di jalan Ampera. Dalam penelitian ini yang menjadi subjek penelittiannya adalah Dekan Fakultas IPPS, Dosen Fakultas IPPS dan Mahasiswa. Teknik pengumpulan data dilakukan dengan observasi langsung, komunikasi langsung dan dokumentasi. Validitas data menggunakan teknik trianggulasi yaitu trianggulasi sumber dan trianggulasi teknik. Teknik analisis data menggunakan deskriptif dengan tahapan analisis, yakni pengumpulan data, reduksi data, penyajian data dan kesimpulan.

\section{HASIL DAN PEMBAHASAN}

\section{Persepsi terhadap Penerapan Prinsip-Prinsip Demokrasi dalam Pemilihan Ketua dan Sekretaris Program Studi IKIP PGRI Pontianak}

Persepsi merupakan suatu proses yang dipelajari melalui interaksi dengan lingkungan sekitar. Persepsi sesorang timbul sejak kecil melalui interaksi dengan 
manusia lain. Sejalan dengan hal itu, Rahmat (1990:64) mendefiniskan pengertian persepsi sebagai: "pengalaman tentang objek, peristiwa atau hubunganhubungan yang diperoleh dengan menyimpulkan informasi dan menafsirkan pesan". Kesamaan pendapat ini terlihat dari makna menyimpulkan informasi dan menafsirkan pesan yang memiliki keterkaitan dengan proses untuk memberi arti. Menurut Asrori (2009:214) pengertian persepsi adalah "proses individu dalam menginterprestasikan, mengorganisasikan dan memberi makna terhadap stimulus yang berasal dari lingkungan di mana individu itu berada yang merupakan hasil dari proses belajar dan pengalaman.” Dalam pengertian persepsi tersebut terdapat dua unsur penting yakni interprestasi dan pengorganisasian. Interprestasi merupakan upaya pemahaman dari individu terhadap informasi yang diperolehnya. Sedangkan perorganisasian adalah proses mengelola informasi tertentu agar memiliki makna.

Selanjutnya, Slameto (2010:102) menjelaskan bahwa persepsi adalah proses yang berkaitan dengan masuknya pesan atau informasi kedalam otak manusia, melalui persepsi manusia terus menerus mengadakan hubungan dengan lingkungannya. Hubungan ini dilakukan lewat inderanya, yaitu indera pengelihat, pendengar, peraba, perasa, dan pencium. Sarlito Wirawan Sarwono (1983: 89), pengertian Persepsi adalah kemampuan seseorang untuk mengorganisir suatu pengamatan, kemampuan tersebut antara lain: kemampuan untuk membedakan, kemampuan untuk mengelompokan, dan kemampuan untuk memfokuskan. Oleh karena itu seseorang bisa saja memiliki persepsi yang berbeda, walaupun objeknya sama. Hal tersebut dimungkinkan karena adanya perbedaan dalam hal sistem nilai dan ciri kepribadian individu yang bersangkutan.

Berdasarkan hasil wawancara dengan berbagai narasumber, maka dapat disimpulkan bahwa pesepsi dosen terhadap penerapan prinsip -prinsip demokrasi dalam pemilihan ketua dan sekretaris program studi pada Fakultas IPPS IKIP PGRI Pontianak sangat positif dan konstruktif terhadap sistem pelaksanaan yang dilakukan selama ini. Sistem pemilihan ketua dan sekretaris program studi sangat demokratis, partisipasi aktif dosen sudah baik, pemilihan dilaksanakan secara jujur, adil, dan terbuka. Selain itu, terdapat kebebasan dalam menyampaikan 
pendapat dan kebebadan dalam memilih calon atau mencalonkan diri. Sistem pemilihan dilakukan secara aman, damai dan kondusif serta masing-masing calon ketua dan sekretaris bersaing secara kompetitif dan profesional. Hal ini dibuktikan dengan sikap menghargai dan menghormati pasangan calon yang menang.

Berkaitan dengan temuan penelitian di atas, bahwa nilai-nilai demokrasi menurut Cipto, et al (2002:31-37) dalam Tukiran Taniredja (2009: 59-63) meliputi:

a) Kebebasan menyatakan pendapat

Kebebasan menyatakan pendapat adalah sebuah hak bagi warga negara biasa yang wajib dijamin dengan undang-undang dalam sebuah sistem politik demokrasi (Dahl, 1971).

b) Kebebasan berkelompok

Berkelompok dalam suatu organisasi merupakan nilai dasar demokrasi yang diperlukan bagi setiap warga negara. .

c) Kebebasan berpartisipasi

Kebebasan berpartisipasi sesungguhnya merupakan gabungan dari kebebasan berpendapat dan berkelompok. Rasa percaya (Trust)

Rasa percaya antara politisi merupakan nilai dasar lain yang diperlukan agar demokrasi dapat terbentuk. Sebuah pemerintahan demokrasi akan sulit berkembang bila rasa percaya satu sama lain tidak tumbuh. Bila yang ada adalah ketakutan, kecurigaan, kekhawatiran, dan permusuhan maka hubungan antar politisi akan terganggu secara permanen. Jika rasa percaya tidak ada maka besar kemungkinan pemerintah akan kesulitan menjalankan agendanya karena lemahnya dukungan sebagai akibat dari kelangkaan rasa percaya.

d) Kerjasama

Kerjasama diperlukan untuk mengatasi persoalan yang muncul dalam masyarakat. Kerjasama yang dimaksud di sini adalah kerjasama dalam hal kebajikan. Kerjasama hanya mungkin terjadi jika setiap orang atau kelompok bersedia untuk mengorbankan sebagian dari apa yang diperoleh dari kerjasama tersebut. 
Dari pengamatan peneliti menunjukkan bahwa proses pemilihan ketua dan sekretaris sangat demokratis dan partisipatif aktif dari dosen sebagai pemilih. Pemilih menentukan pilihannya sesuai dengan hati nurani tanpa ada tekanan dari pihak manapun. Setelah proses pencoblosan selesai, maka tahap berikutnya adalah menghitung suara dengan disaksikan oleh saksi, sehingga tidak ada kecurangan. Hal ini membuktikan bahwa prinsip demokrasi dijalankan dengan baik dan lancar. Indikator tersebut dibuktikan dengan calon pasangan yang kalah dalam pemilihan menerima kekalahan, dan menjunjung sportifitas dalam pemilihan tersebut.

Berdasarkan hasil observasi tersebut di atas, maka peneliti simpulkan bahwa penerapan prinsip demokrasi berjalan dengan baik dan dan menjunjung tinggi sistem demokrasi yang ada. Prinsip demokrasi yang dijalankan yaitu prinsip demokrastis, kebebasan dan menjunjung tinggi hak dan kesetaraan, memenuhi prinsip keadilan dan kejujuran, serta bersifat terbuka dan menjunjung tinggi peraturan yang telah dibuat oleh panitia pemilihan.

Dari temuan penelitian dan toeri di atas menunjukkan bahwa penerapan pinsip demokasi yang dilaksanakan pada sistem demokrasi dalam pemilihan ketua dan sekretaris prodi pada Fakultas IPPS IKIP PGRI Pontianak berdasarkan pada prinsip demokrasi langsung, prinsip kebebasan dalam menyatakan pendapat dan dalam menentukan pilihan, prinsip kejujur dan keadilan serta menjunjung tinggi hak dan prinsip menghargai dan menghormati.

\section{Faktor-Faktor yang Mempengaruhi dalam Penerapan Prinsip-Prinsip Demokrasi dalam Pemilihan Ketua dan Sekretaris Program Studi IKIP PGRI Pontianak}

Berdasarkan hasil wawancara dengan narasumber, maka dapat disimpulkan bahwa terdapat faktor yang mempengaruhi penerapan prinsip demokrasi dalam pemilihan ketua dan sekretaris prodi pada Fakultas IPPS yaitu, faktor kesadaran diri seseorang terhadap keterlibatan aktif dalam memilih dan menentukan calon pemimpin. Faktor kepemipinan institusi kampus juga mempengaruhi sistem dan budaya demokrasi. Faktor lainnya yaitu dukungan moril dari lembaga kampus, serta faktor berikutnya adalah sarana dan prasarana 
yang baik akan mendukung kelancaran dan keberhasilan pelaksanaan sistem demokrasi.

Hasil pengamatan peneliti terhadap faktor yang mempengaruhi penerapan prinsip-prinsip demokrasi dalam pemilihan ketua dan sekretaris prodi dapat disimpulkan bahwa, penyelenggaraan pemilihan kapro dan sekpro di dukung oleh kampus baik dalam segi dukungan moril dan materil. Dukungan moril yang diberikan adalah diberikan kepercayaan penuh kepada panitia untuk melaksanakan pemilihan tersebut. Dukungan materil yang diberikan adalah insentif operasional panitia penyelengara. Hasil pengamatan yang ditemukan adalah pemimpin institusi, dalam hal ini rektor sangat mendukung penyelenggaraan pemilihan kapro dan sekpro tersebut. Hal ini ditunjukkan dengan menghadiri rapat persiapan panitia dan ikut memantau jalannya pelaksanaan pesta demokrasi tersebut. Pelaksanaan prinsip demokrasi pada pemilihan tersebut sudah menunjukkan nilai-nilai dalam prinsip demokrasi yang demokratis, jujur, adil, terbuka dan bebas dalam menyampaikan pendapat dan bebas menentukan pemimpin.

Dari hasil pengamatan peneliti, pelaksanaan pemilihan tersebut berjalan dengan baik tanpa ada hambatan dan gangguan dari pihak manapun, serta tidak ada intervensi dari pihak manapun yang mempunyai kepentingan. Faktor kepedulian, partisipasi aktif, kesadaran sangatlah menentukan dalam keberhasilan sebuah sistem demokrasi. Selain itu, dari pengamatan peneliti menemukan bahwa sarana dan prasaran dalam penyelenggaraan pemilihan tersebut masih belum memadai dan minim yang dibutuhkan. Misalkan masih minim ada spanduk atau benner yang ditempel dalam pesta demokrasi tersebut, sistem sosialisasi dan pelaksanaan masih sebatas lisan, sangat perlu disampaikan melalui media massa seperti koran. Selain itu, hasil pengamatan peneliti juga menemukan bahwa kertas dan kotak suara dibuat dari kertas dan kardus biasa.

Faktor-faktor yang mempengaruhi prilaku demokrasi beraneka ragam, diantaranya adalah kesadaran akan hak dan kewajiban sebagai warga negara dan kepercayaan kepada pemerintah. Selain dari itu faktor-faktor lainnya adalah status sosial, status ekonomi, afiliasi politik orang tua dan pengalaman 
berorganisasi (Surbakti, 1992: 144). Disamping itu pengetahuan tentang demokrasi juga mempengaruhi prilaku demokrasi. Demokrasi bergantung pada warga negara yang berpendidikan dan berpengetahuan (Ravitch, 1989: 9). Bila kita ingin mewujudkan masyarakat yang demokratis tingkatkanlah pendidikan dan pengetahuan serta berprilakulah sesuai dengan nilai-nilai demokrasi seperti yang diungkapkan di atas. Suatu hal yang sangat penting dalam mewujudkan demokrasi adalah taat akan nilai dan aturan-aturan hukum yang telah disepakati, karena nilai dan aturan hukum itulah yang membingkai demokrasi.

Berkaitan faktor-faktor yang dapat mempengaruhi tinggi dan rendahnya partisipasi seseorang dalam melihat suatu persoalan dalam lingkungannya, dikemukakan adanya empat tipe partisipasi, yaitu: (Jeffry M Paige, dalam Surbakti, 1999: 144)

1) apabila seseorang memiliki kesadaran politik dan kepercayaan kepada pemerintah yang tinggi, maka partisipasi politik cenderung aktif;

2) apabila seseorang tingkat kesadaran politik dan kepercayaan kepada pemerintah rendah, maka partisipasi politik cenderung pasif-tertekan (apatis);

3) apabila kesadaran politik tinggi tetapi kepercayaan kepada pemerintah sangat rendah, maka akan melahirkan militan radikal; dan

4) apabila kesadaran politik sangat rendah tetapi kepercayaan kepada pemerintah sangat tinggi, maka akan melahirkan partisipasi yang tidak aktif (pasif).

Dari berbagai hal yang berkaitan dengan partisipasi di atas, terlihat bahwa problematika partisipasi dalam kehidupan berdemokrasi menjadi suatu masalah yang dapat diperdebatkan. Tuntutan adanya partisipasi dalam suatu negara demokrasi pada satu sisi merupakan suatu keniscayaan, namun di sisi yang lain dipertanyakan apakah partisipasi itu dapat dilakukan dalam kerangka kebebasan dan persamaan warga negara dalam penyelenggaraan suatu negara. Permasalahan tersebut kemudian menuntun pada pertanyaan, apakah pemerintahan yang demokratis itu tergantung pada ada dan tidaknya partisipasi dari masyarakat dalam membuat keputusan pemerintahan. Jika adanya partisipasi ini menjadi 
suatu ukuran dalam proses pengambilan keputusan yang demokratis, maka ukuran apakah untuk menentukan bahwa suatu partisipasi masyarakat itu merupakan keinginan bersama dalam masyarakat.

\section{SIMPULAN}

Berdasarkan hasil penelitian dan pembahasan, secara umum penelitian ini dapat disimpulkan bahwa persepsi dosen terhadap penerapan prinsip -prinsip demokrasi dalam pemilihan ketua dan sekretaris Program Studi pada Fakultas Ilmu Pendidikan Dan Pengetahuan Sosial sudah berjalan dengan baik dan harus tetap dijaga, dipertahankan serta membudayakan prinsip-prinsip demokrasi pada setiap sistem pelaksanaan demokrasi pada IKIP PGRI Pontianak.

Penerapan prinsip-prinsip demokrasi dalam pemilihan ketua dan sekretaris Program Studi pada Fakultas Ilmu Pendidikan Dan Pengetahuan Sosial Pada IKIP PGRI Pontianak sudah berjalan dengan baik. Pelaksanaan prinsipprinsip demokrasi yang dilaksanakan yaitu, (1) prinsip demokratis, dimana sistem pemilihan dilaksanakan secara langsung, umum, jujur dan adil. (2) prinsip kebebasan, bebas memilih sesuai dengan hati nuraninya, saling menghargai pendapat, mendukung dan bekerjasama. (3) prinsip partisipasi, adanya keterlibatan dan partisipasi aktif dosen dalam mendaftar sebagai pasangan calon ketua dan sekretaris prodi, serta ikut aktif berpartisipasi dalam pemilihan. (4) prinsip kesetaraan, adanya kesempatan yang sama dan hak yang sama dalam mencalonkan diri berdasarkan persyaratan yang ditentukan panitia penyelenggara. (5) prinsip kejujuran, sistem pemilihan dilaksanakan secara jujur tanpa ada kecurangan dan kebohongan. (6) prinsip saling menghargai dan menghormati, dimana perbedaan pendapat,visi, misi dan program kerja serta kalah dalam pemilihan tetap dijunjung tinggi dengan.

Faktor-faktor yang mempengaruhi penerapan prinsip-prinsip demokrasi dalam pemilihan Ketua dan Sekretaris Program studi di IKIP PGRI Pontianak yaitu faktor kesadaran politik, faktor kepemimpinan institusi yang profesional dan kompeten, faktor situasi dan kondisi politik, faktor dukungan lembaga, dan faktor sarana dan prasarana. 


\section{DAFTAR PUSTAKA}

Asrori, M. (2009). Psikologi Pembelajaran. Bandung: CV Wacana Prima.

Budiarjo, Miriam. (2005). Dasar-dasar Ilmu Politik. Jakarta : Gramedia Pustaka Utama.

Branson, M.S. (1998). The Role of Civic Education, A Fortcoming Education Policy Task Force Position Paper From the Communitarian Network.

Fraenkel, J.R. (1987). How To Teach About Values: An Analytic Approach. Englewood Cliffs. New Jersey: Prentice-Hall Inc.

Gaffar, A. (2004). Politik Indonesia Transisi Menuju Demokrasi. Yogyakarta: Pustaka Pelajar Offset.

Gandal, J.E. dan Finn, E.S. (1992). Teaching Democracy, Freedom Paper USA, (2) $1-28$

Meleong, L. (2003). Metodologi Penelitian Kualitatif. Jakarta: PT. Remaja Rodaskarya.

Rahmat, J. (1990). Psikologi Komunikasi. Bandung: Remaja Karya.

Sanusi, A. (2006). Memberdayakan Masyarakat Dalam Pelaksanaan 10 Pilar Demokrasi Dalam Pendidikan Nilai Dan Moral Dalam Dimensi Pendidikan Kewarganegaraan. Bandung: Laboratorium Pendidikan Kewarganegaraan FIPPS UPI.

Saripudin U. Dkk. (2003). Materi dan Pembelajaran PKn SD, Pusat Penerbitan Universitas Terbuka, Jakarta.

Sarwono \& Sarlito. (1976). Pengantar Umum Psikologi. Jakarta : PT. Bulan Bintang

Sumantri, S. (1984). Pembahasan Konsep dan Nilai Demokrasi. Bandung: Panitia Seminar Jurusan PPKn IKIP.

Somantri, Numan. (2001). Menggagas Pembaharuan Pendidikan IPS. Bandung: PT. Remaja Rosda Karya

Slameto. (2010). Belajar dan Faktor-faktor yang Mempengaruhinya. Jakarta: Rineka Cipta 
SOSIAL HORIZON: Jurnal Pendidikan Sosial, Vol. 5, No. 1, Juni 2018

Taniredja, Tukiran. (2009). Pendidikan Kewarganegaraan di Perguruan Tinggi Muhammadiyah. Purwokerto: CV. Alfabeta.

Tilaar. (1999). Beberapa Agenda Reformasi Pendidikan Nasional dalam Perspektif Abad 21. Tera Indonesia, Jakarta.

Walgito, Bimo. (1989). Pengantar Psikologi Umum. Surabaya: Bina Ilmu.

Winataputra dan Budimansyah. (2007). Civic Education (Konteks, Landasan, Bahan Ajar dan Kultur Kelas. Bandung: Program Studi PKn SPs UPI.

Winataputra, Udin. S. dkk. (2008). Materi dan Pembelajaran PKN SD. Jakarta: Universitas Terbuka. 